\title{
Legal Protection for Winners of Dependent Rights Execution Auctions Through Parate Executie
}

\author{
Shohib Muslim \\ State Polytechnic of Malang, Soekarno Hatta St., Malang City, East Java, Indonesia \\ Khrisna Hadiwinata \\ State Polytechnic of Malang, Soekarno Hatta St., Malang City, East Java, Indonesia \\ Hudriyah Mundzir \\ State Polytechnic of Malang, Soekarno Hatta St., Malang City, East Java, Indonesia
}

\begin{abstract}
The arrangement of the execution of dependent rights by way of Parate Executie in the Dependent Rights Act aims to provide convenience to creditors and auction winners in fulfilling their receivables while the debtor wanprestasi, i.e. creditors can sell the object of Dependent Rights over their own power without having to go through the judiciary. It's just that the ease that the creditor has in fact cannot be utilized because there is a difference in the interpretation of the arrangement regarding the execution parate in the Dependent Rights Law (Law No. 4 of 1996 concerning the Right of Dependents on Land And Objects Related to Land). The research method used is normative juridical with primary data and secondary and tertiary data obtained through literature studies and field surveys with data collection tools in the form of interviews. Legis Ratio of Article 6 of Law No. 4 of 1996 concerning The Right of Dependents on Land And Objects Related to Land is the procedure of execution as intended in Article 6 of the UuHT, the first creditor of the holder of Dependent Rights simply submits an application for the implementation of the auction to the State Auction Office. The right of creditors to sell the object of dependent rights on their own power in public, has been submitted by law itself to the creditors of the first dependent rights holder. That authority is not obtained from the grantor of dependent rights but is already in itself to him, on the basis of the law itself giving to him. Legal protection provided to the Winner of the Auction of the execution of Dependent Rights by providing real benefits in the form of convenience and efficiency of time and other conveniences to all parties for the process of executing dependent rights.
\end{abstract}

Keywords: Legal Protection, Parate executie, Auction.

DOI: $10.7176 / \mathrm{JLPG} / 114-05$

Publication date:October $31^{\text {st }} 2021$

\section{INTRODUCTION}

Enacting the Dependent Rights Act dated April 9, 1996, the right of dependents is the only institution of land guarantee rights in the written national land law. Dependent rights are credits that provide protection and privilege to certain creditors. The law regarding credit guaranteed with the right of dependents governs the agreement and the relationship of certain receivable debts between creditors and debtors which includes among them is the right to sell the auction of certain property designated as collateral to further take repayment from the proceeds of the sale of the guarantee if the debtor defaults.

The Civil Code has also provided safeguards to creditors in distributing credit to debtors, namely by providing general guarantees according to articles 1131 and 1132 of the Civil Code which determines that all the debtor's material property is either moving or immovable, existing and new will exist, to be a guarantee of all engagements with creditors. If there is a default, then all the debtor's property will be sold at auction and divided according to the small receivables of each creditor. But because the protection derived from the general guarantee is felt still does not provide a sense of security to creditors, so in the practice of lending, banks feel the need to ask for special guarantees, especially those of a material nature. Therefore, the presence of the Dependent Rights Act as a substitute for mortgage and credietverband institutions is very much beneficial.

The intended purpose of the granting of dependent rights is to provide legal protection and certainty to all parties and also fulfill the principle of publicity. Article 1 paragraph 1 of uuht regulates the provisions regarding the granting of dependent rights from debtors to creditors in connection with debts guaranteed with dependent rights. Granting the right to give a primary position to the creditor concerned. By the possibility of granting dependent rights is as a guarantee for the repayment of debtors to creditors in connection with the credit loan agreement in question.

The process of carrying out the execution of dependent rights carried out by creditors is actually not difficult. Because in addition to the certificate of Dependent Rights serves as a letter of proof of the existence of Dependent Rights, where on the certificate is affixed with the words "For the Sake of Justice Based on The Supreme Divinity", which has the same executive power as a court decision that already has permanent legal 
force, the holder of the first Dependent Rights also has the right to carry out direct execution of the object of Dependent Rights that is used as a guarantee of credit, when the debtor disbelies promise. Which is based on the power granted by the debtor as well as by law to the creditors. (Harahap. 2001).

Based on article 6 of the Uuht if the debtor injured the promise (wanpretasi) holder of the first dependent rights has the right to sell the object of dependent rights to his own power through public auction and repayment of receivables taken from the auction proceeds. This is what is called parate execution as also mentioned in article 20 of the UUHT. Then refer to the formulation of article 6 of the UUHT the execution process can be carried out without interference or through the court. In other words, there is no need to request a fiat execution from the Chief Justice of the District Court, because the right of the holder of the first dependent right to sell the object of dependent rights to his own power is a right under the law. So without a treaty, that right was born. While against Grosse the deed itself can be directly executed as befits the judge's ruling with the mechanism as mentioned in article 224 HIR through warning, confiscation and sale. Auctioneers sometimes refuse to make public sales in public.

Through Article 6 of the Uuht, lawmakers intend to give a strong seat to dependent rights holders, namely by granting a very powerful right, called execution parate. The holder of the first Dependent Rights does not need to seek prior approval from the dependent and does not need to ask for the determination of the Chairman of the local District Court to carry out the execution of the object of dependent rights. The holder of the first Dependent Rights only needs to apply to the Head of the local State Auction Office for the implementation of the general auction in the framework of the execution of the dependent rights object.

General sale or auction officially entered into law in Indonesia since 1908, with the enactment of Vendu Reglement, Ordonantie February 28, 1908 Staatblad in 1908 Number 189 jo Stb. 1941 N0. 3 and Vendu Instructie announced in Staatblad 1908 Number 190 jo Stb. 1930 No. 85 which is still valid, under Article II of the Transitional Rules of the 1945 Constitution. Vendu Reglement has undergone changes and additions, although its status is only reglement but because it is the only auction regulation and its implementation is regulated by Government Regulation, Vendu Reglement may be equated with legislation.

Based on Article 20 of the Uuht mentions that the object of Dependent Rights is sold through public auction or according to the procedures specified in the laws and regulations for the repayment of dependent rights holders. It is as stated in Article 200 paragraph (7) of Het Herziene Indonesisch Reglement (HIR) that the grantor of dependent rights, i.e. the debtor is no longer allowed to prevent the auction and pay all his debts. (Susanto, 1996:63).

The implementation of auctions in Indonesia can be done through the procedures set out in The Minister of Finance Regulation No. 93 / PMK.06 / 2010 on The Instructions for The Implementation of Auctions, but even though it has been regulated in a Regulation of the Minister of Finance, in practice, there are still many lawsuits for cancellation of auctions filed with the District Court. Auctions that are canceled based on the court's decision, then the implementation of the auction as a form of preferential rights granted by law on dependent rights becomes uncertain. Thus it is futile to grant preferential rights to dependent rights holders, but in the end after the sale of dependent rights objects, it was canceled by a court ruling which resulted in the dependent rights and the sale of dependent rights objects considered non-existent. The cancellation of the auction through a court ruling also reflects a lack of legal protection against the winner of the auction.

In connection with the fact that parate executie in practice cannot be carried out properly and quickly against the object of dependent rights and this can cause legal uncertainty in its implementation will still invite and become a long and interesting discussion scientifically academic. This research will at least reveal some important sides of various legal problems that arise and become obstacles in the implementation of parate executie as mandated by law.

\section{PROBLEMS}

1. What is the Legis Ratio of Article 6 of Law No. 4 of 1996 concerning The Right of Dependents on Land And Objects Related to Land?

2. What is the legal protection given to the Winner of the execution auction based on Article 6 of Law No. 4 of 1996 concerning the Right of Dependents on Land Rights along with Objects Related to Land?

\section{LITERATURE REVIEW}

\subsection{Legal Protection Theory}

The theory used in this study is the theory of legal protection from Philipus M. Hadjon as a knife of analysis to observe and analyze the problem, this theory proposes that: Legal protection is the protection of dignity and dignity and recognition of human rights owned by legal subjects in the state of law based on the provisions of applicable law in that country to prevent arbitrariness. Legal protection is generally in the form of a written regulation, so it is more binding and will result in sanctions that must be imposed on those who violate it. 
(Hadjon, 2005)

According to Philip M. Hadjon, two types of legal protection are distinguished, namely:

1.Preventive legal protection that aims to prevent problems or disputes.

2.Repressive legal protection aimed at resolving problems or disputes that arise.

\subsection{Execution Parate Overview}

The term parate execution is implicitly never contained in the laws and regulations. Parate execution from the word paraat which means the right is ready in the hands of creditors to sell collateral objects in public on the basis of their own power. The authority to sell on one's own power or execution parate is granted if the debtor defaults, then the creditor can carry out the execution of the object of guarantee without having to ask for fiat from the Chief Justice. Parate execution that was originally regulated in the hypocrisy (article 1178 paragraph (2) BW) then could not be denied adopted by uuht, which in article 6 of the UUHT. For the clear substance of article 6 of the Uuht referred to is: "If the debtor is injured by the promise, the holder of the first Dependent Rights has the right to sell the object of dependent rights on his own power through public auction and take the repayment of his receivables from the proceeds of the sale."

As a guarantee institution, Dependent Rights are guaranteed rights imposed on land rights as referred to in Law No. 5 of 1960, on the Basic Rules of Agrarian Principals. The guarantee agreement that gives birth to this Dependent Right is made by the parties with the aim of completing the principal agreement which is generally a debt-receivable agreement or credit agreement. So that an understanding can be drawn, that the legal relationship between the parties is woven by 2 (two) types of agreements, namely credit agreements as the main agreement and guarantee agreements as additional agreements (accessoir).

A strong guarantee institution, in General Explanation No. 3 of uuht, the right of dependents has 4 (four) main characteristics, namely: Giving the position that takes precedence or precedes the holder; Always follow the object guaranteed in the hands of whoever the object is; Fulfilling speciality and publicity so as to bind third parties and provide legal certainty to interested parties; And easy and definitely executed.

In order for the ease and legal certainty of the execution of dependent rights, especially execution parate if the debtor is injured by the promise, it is expected to be realized in real terms. The execution of dependent rights is easy and certain is one of the principles of dependent rights outlined in article 20 of the Uuht, the execution of dependent rights according to 3 (three) characteristics, namely:

1.The right of holders of the first dependent right to sell the object of dependent rights as referred to in article 6 of the UUHT (parate execution);

2.The executory title contained in the certificate of Dependent Rights as referred to in article 14 paragraph (2); and

3.Execution through the application of dependent rights under the hands of the agreement of the giver and holder of dependent rights (article 20 paragraph (2) of Law No. 4 of 1996 concerning uuht).

\section{RESEARCH METHODS}

This research belongs to normative legal research, which is research that examines laws and regulations in a coherent legal system. (Wignjosoebroto.1995:5) In this case a positive law that applies at a given time and is published as a product of certain political power that has legitimacy. There are also those who state that while the problems and objectives of legal studies reflect the ideal realm of law (philosophy, legal principles, legal rules, systematic logic and the basic understandings of law), then the research is normative or doctrinal. (Hadith, 2005:5). As a legal research that is normative-prescriptive with regard to the execution of dependent rights, in order to provide an understanding of legal issues (Legal Issue) more holistically will be used several approaches (Hartono, 1994: 123) namely:

First the philosophical approach, through reflection on the various rules of law to be analyzed as well as about the foundation of reality as well as the function of philosophy of law. Namely reviewing the law properly and correctly in three areas of ontology, epistimology and axiology Both approaches to legislation (Statute Approach) namely by reviewing and researching laws and regulations in the field of Dependent Rights and banking. and other laws and regulations related to legal protection for parties in the execution of dependent rights.

The next concept approach (Conceptual approach) is an approach by understanding abstract elements that exist in the mind. According to Ayn Rand, philosophically the concept is the mental integration of two or more units that are isolated according to characteristics and that are united by a distinctive definition. (Suhariningsih, 2007:39). The concept approach in this research is intended to examine concepts related to laws and regulations and legal protection for parties in the execution of dependent rights. The fourth comparative approach to compare laws and regulations and comparisons between legal systems that have legal objectives that are derived into the principles and norms that govern them.In this study the comparative approach is done by comparing between dependent rights laws with laws and other regulations related to the execution of dependent rights 
objects especially in aspects of treaty and guarantee law, after previously comparing legal objectives.

The fifth is the Analytical Approach, a term used by Johnny Ibrahim to analyze the basic understanding of law, understanding of law, and so on. This approach is important because the content of law is something that lives and moves dynamically in addressing complex legal issues. The historical approach is used to look at and examine the course of dispute resolution and its relation to parate executie.

\section{DISCUSSION}

5.1. What is the Legis Ratio of Article 6 of Law No. 4 of 1996 concerning The Right of Dependents on Land And Objects Related to Land?

Actually, the term "parate executie" implicitly never contained in the laws and regulations. The term parate executie as described in the previous section, etymologically derived from the word "paraat" means ready in hand, so that parate executie is said to be a means of execution ready at hand. According to the legal dictionary, parate executie means direct execution without going through the process (court or judge). (Satrio, 2005;276).

Subekti argues, parate executie is running itself or taking it for himself what is rightfully, in the sense that without the intermediary of the judge, which is aimed at a guaranteed item to further sell the goods themselves. Parate executie is an execution carried out by the holder of the right of guarantee (lien and mortgage) without the help or interference of the District Court, but only based on the assistance of the State Auction Office only. (Subekti, 69). Or in other words, parate executie is carried out without requesting fiat execution or permission from the District Court. So that the term "parate executie", can be said to be a stipulative definition of convience, the intent to emphasize new elements whose nature to give special meaning, can be the introduction of new terminology or give a new understanding to the existing term. The reason is to introduce a new term. So that a term is enough to replace one description or many words. So that the phrase "authority to sell on one's own power" is enough with the istiah "parate executie".

Ease of use of the means of Article 6 of uuht due to the implementation of the sale of dependent rights objects only through public auctions, without having to ask for the fiat of the Chairman of the District Court. Such ease mainly indicates time efficiency compared to the execution of court rulings that already have permanent legal force. This is considering the procedure of execution through the legal formalities of the event, the process that is passed takes a long time and complicated the procedure. Parate executie is cheaper than the execution of executie using the executory title, because it does not bear the cost to apply for the determination of the executie to the Chairman of the District Court. Because it is feared that creditors will be reluctant to provide credit with mortgage guarantees (Dependent Rights), especially if the amount of the bill is not large. (Nierop, 1937:155). Of course, it will also be felt not equal if the execution through the court, especially about the amount to be billed with all efforts, costs and especially the time needed to get back bad credit, then with article 6 of the law the creditor will be protected from the actions of the debtor who is not appropriate, unworthy or even not in good faith. Article 6 of the Uuht is prepared by the legislator as the main buffer pole for creditors (banks) in obtaining the acceleration of repayment of receivables, so that receivables that have been returned to creditors then the finance can be used for the rotation of the economic wheels, then there is no doubt that Article 6 of the UUHT is the legal basis for the enactment of parate executies when the debtor wanprestasi, which is used as an excellent means for adjustment to the needs of the economics.

The birth of a law should not mean that the device made and then perfect, however the law is not the final product. It is true what $M$. Isnaeni stated in one of his scientific works as that has been revealed in the background sub-chapter of the problem in the previous description, that it could be in the material content of the law there are inconsistencies, then blurred or there is a conflict of norms in the regulation. As well as the arrangement of the procedure for the implementation of parate executie needs to be studied so that the director is more clear what is desired by the establishment of the UUHT.

When viewed from the history of the birth of Dependent Rights is a substitute for the mortgage institution devoted to land. At the time of the validity of the hypocrisy institution is known beding van eigen machtige verkoop stipulated in Article 1178 paragraph (2) of B.W., which in essence the promise of auction sales must be done in the manner as stipulated in Article 1211 B.W., which stipulates that the sale of the object of the right of guarantee must be done according to local custom, in front of an official. The intended Official is in accordance with Article 1a of the Auction Regulation or Vendu Reglement Ordinance of February 28, 1908 LN. 1908-189, which specifies that: "Public sale shall not be held except in front of the auctioneer". Meanwhile, the "auctioneer" (Article 48), is meant to be the bookkeeper or the assistant bookkeeper, who is assigned by the Supervisor of the State Auction Office to conduct a general sale. Parate execution is an execution carried out alone by the holder of the right of guarantee (lien and mortgage) without the help or intervention of the District Court, but only based on the assistance of the State Auction Office only. (Soemitro, 1987:1).

The execution arrangements under Articles 224 H.I.R. and 258 R.Bg. are executions aimed at grosse acte mortgage (Certificate of Dependent Rights) and grosse acte debt recognition. Both grosse acte is meant, it does have executory rights, which means the two grosse acte have the power as a court decision that has permanent 
legal power. So the execution is subject and obedient as the implementation of a court decision, which must be carried out on the orders of the Chief Justice of the District Court. It would be inappropriate if the execution of ex-Article 224 H.I.R. It's called a parate executie. This arrangement becomes excessive and will lead to incessant cross-opinions and even lead to conflicting norms. It can be said that the establishment of UUHT in giving authority (rights) to creditors of the first dependent rights holder is inconsistent (in-consistency). The existence of such consistency must be addressed immediately to reflect certainty for the parties in particular.

For more details it is necessary to review general explanation Number 9 of uuht which states: "one of the characteristics of strong dependent rights is easy and certain in the execution, if the debtor is injured promise. Although in general the provisions on execution have been regulated in the applicable Civil Procedure Law, it is deemed necessary to include specifically the provisions on the execution of Dependent Rights in this law, that is, which regulates the institution of parate executie as meant by Article 224 of the Updated Indonesian Reglemen (Het Herziene Inlands Reglement) and Article 258 of the Reglemen of Legal Events for The Outer Regions of Iawa and Madura (Reglement tot Regeling van her Rechtswezen in de Gewesten Buiten Java en Madura)."

Furthermore, when general explanation number 9 of uuht is associated with the explanation of Article 14 paragraphs (2) and (3) which states: "the irahs listed on the certificate of dependent rights are intended to affirm the existence of executive power on the certificate of dependent rights, so that if the debtor is injured by the promise, then the certificate of dependent rights is executed as well as the court's decision that has obtained permanent legal force, through ordinances and by using parate executie institutions in accordance with civil event law".

Understanding of the two explanations, shows the will of the Law-Shaper through authentic interpretation as follows:

1. Regulating the implementation of parate executie as intended by Article 224 H.I.R./258 R.Bg.;

2. The execution of the Certificate of Dependent Rights through ordinances and by using parate executie institutions in accordance with civil procedure law.

Both General Explanation Number 9 and Explanation of Article 14 paragraph (2) of the Uuht is important to note with regard to the right to sell on one's own power, as referred to in Article 6 of the Uuht, it can be interpreted that how to exercise creditor rights by using parate executie is equated with the procedure of execution of the certificate of Dependent Rights, namely by using procedures in accordance with the Civil Procedure Law that must be through permission and at the order of the Chairman of the District Court, This means that if the debtor is completely defaulted, then the holder of the first Dependent Rights can carry out the promise by selling the auction of the Object of Dependent Rights to his own power (parate execution) based on Article 224 H.I.R./ Article 258 R.Bg.

The execution parate should not be based on Articles 224 H.I.R. and 258 R.Bg., as mentioned by general explanation number 9 and explanation of Article 14 paragraphs (2) and (3). Instead, the execution was carried out without asking for fiat from the Chief Justice of the District Court. Both explanations when connected with Article 6 of uuht, then constructed juridically, then there are obstacles in the procedure of implementation of parate executie described below.

First, the Establishment of uuht provides an understanding of the implementation of parate execution objects of dependent rights causing double meaning, meaning one side of its implementation through general auction (Article 6 uuht) but on the other hand must get fiat from the Chairman of the District Court (based on Pasa1224 H.I.R./258 R.Bg.). The meaning of double gives rise to a vague understanding (vage norman). This shows on the other hand the inconsistent nature of the Establishment of UUHT and on the other hand, its image of the value of legal certainty is never certain.

Second, if the parate executie is reviewed from its nature or law. Legal science can make theories about how to apply law. This is a practical aspect of legal science. The implementation of the law is very important for every type of society. The substance of the law, theoretically, could be good, because it carries out the demands of its people. But often not operational, because there is no special institution appointed to implement the law, it can also be the law is not operational because of complications of the requirements to implement the law. What is in the rule of law, reflects the will of society, and can theoretically be used. As for if it cannot be implemented, of course, it does not meet all the requirements so that the law can be applied. The result is only a good law on paper, but bad to implement. In reality the implementation of the law must not deviate from its substance. It often deviates from the subject of legal objectivity. Procedural law cannot be enforced above (beyond) the substance of its law. Thus, the practical aspect of legal science bridges the gap between its implementation and legal substance. According to Peter Mahmud, rules that are procedural should not set aside or deviate from substantive provisions.

Furthermore, if Article 6 of the Uuht is reviewed from the nature of the law is a regulation that is meteriil law which contains the nature of formil law or if the term given by Sudikno is a material law in which it contains formil law. This can be understood by reading the substance of Article 6 of the Uuht, which states: "If the Debtor is injured by the promise, the holder of the first Dependent Rights has the right to sell the object of dependent 
rights on his own power through public auction and take the repayment of his receivables from the proceeds of the sale".

The entry into force of creditors of the first Dependent Rights holder to sell the object of dependent rights on their own power through general auction conditions if the debtor is injured promise. The intention through a general auction means without having to ask for fiat from the Chairman of the District Court. If the execution parate must be through and at the behest of the Chairman of the District Court (Article 224 H.I.R.), it can be interpreted as deviating from Article 6 of the Uuht which is a substantive regulation. Therefore, if carrying out execution parate must be through the fiat of the Chairman of the District Court, it means to deviate from the rules of Article 6 of the Uuht. Therefore, the form of regulation of the implementation of parate execution of dependent rights objects, which are procedural in nature has deviated from substantive rules. Deviant rules are certainly not for use but are worthy and worthy to be ignored or even not necessary to use because it can be an obstacle to one of the legal purposes of usability (zwekmaszigkeit).

Third, The implementation of parate execution of Dependent Rights by the Establishment of UUHT, is not based on norms in the body that specifically regulate the material parate execution (Article 6 UUHT), but rather uses authentic interpretation, which refers to the formulation of section General Explanation Number 9 and Explanation of Article 14 paragraph (2) and (3) uuht, which regulates the execution material of the Certificate of Dependent Rights. So that the implementation based Article 224 H.I.R./258 R.Bg., must obtain the fiat of the Chairman of the District Court. Thus implicitly the basis used by the Establishment of UUHT against the implementation of execution parate, does not have binding power.

The implementation of parate execution objects of Dependent Rights, based on 2 (two) conflicting execution regulations, one side based on Article 6 of the Uuht, one side based on Article 224 H.I.R./258 R.Bg., so that there is a conflict of norms. As a result, there are no facilities originally provided by law for creditors of first dependent rights holders when the debtor disbelies. Actually to implement the provisions of Article 6 of the Dependent Rights Act The implementation instructions are regulated in the Circular Letter of the State Receivables and Auction Agency Number: SE-21/PN/1998 Concerning Instructions for the Implementation of Article 6 of the Dependent Rights Act and the Circular Letter of the State Receivable and Auction Agency Number: SE-23/PN/2000.

\subsection{Promises Under Article 11 of uuht as a creditor protection clause}

The Deed of Granting Dependent Rights can be included in promises that are facultative and have no influence on the validity of the Deed of Granting Dependent Rights. With the inclusion of these promises in the Act of Granting Dependent Rights which is then registered with the Land Office, the promises also have binding power to third parties. The promises in question are mentioned in Article 11 paragraph (2) of uuht, namely:

a.A promise that limits the authority of the grantor of dependent rights to rent the object of dependent rights and/or determine or change the term of the lease. and/or receive the rent in advance, except with the prior written consent of the dependent rights holder;

b.A promise that limits the authority of the granter of dependent rights to change the form or susnnan object of dependent rights except by conflict] written in advance from the holder of the dependent rights;

c.Promises that limit the authority of the grantor of dependent rights to rent objects of dependent rights and/or determine or change the term of rent and/or receive rent in advance, and promises that limit the authority of the grantor of dependent rights to change the shape or arrangement of dependent rights objects, except with the prior written consent of the holder of the dependent rights.

d. The promise that gives authority to the holder of dependent rights to manage the object of Taggungan Rights based on the determination of the Chairman of the District Court whose hukunmya area includes the location of the object of Dependent Rights if the debtor is really injured by the promise;

The inclusion of these promises in the Act of Granting Dependent Rights which is then registered with the Land Office, then the promises also have binding power to third parties. The promises as mentioned in the law (Article 11 paragraph (2) of the Uuht), do not mean that such promises can be promised by creditors because the law declares them in order (or provides such an opportunity). The law in this case only reminds creditors of the possibility to promise such promises, because basically, people can promise anything, as long as it does not conflict with coercive laws, manners (decency) and public order.

When examined the words in Article 11 paragraph (22 UUHT, which states: "In apht "can" be included promises ...", the understanding of the word "can" intended by the law is to allow creditors to promise clauses in the form of promises that have been offered as specified in Article 11 paragraph (2) of uuht to creditors to promise these promises or not, then the law gives the option to promise them. According to Remy Sjahdeini, Article 11 paragraph (2) of uuht is facultative and not limitative, meaning because the promises can be included or not included, either partially or completely, while they are not limitative because they can also be promised 
promises other than promises that have been made in Article 11 paragraph (2) of the UUHT." (Sjahdeni:65)

In practice the promises as mentioned there can almost be said to always be promised by creditors, therefore for the sake of making it easier for the parties the promises have been printed in the blank of the APHT form. So on the basis of what is mentioned in Article 11 paragraph (2) of uuht, already printed in the blanko apht form, the clause agrees the parties can be removed from the blanko concerned. Since dependent rights must be promised, in principle there must be an agreement between the two parties, meaning if the guaranteer to agree or refuse to promise such promises. If between the creditor and the debtor agrees by signing the APHT, then the promises intended are the embodiment of the seriousness and good faith of the debtor, with these promises then if the debtor defaults, the creditor is given the right or authority as promised. This is for and to protect the interests of creditors when dabitor defaults and does not immediately pay off creditor receivables.

Furthermore, regarding the promise to sell on one's own power (parate executie) contained in Article 11 paragraph (2) letter e of UUHT, contained in the Act of Granting Rights of Tangglmgan (APHT), mentioning:

"the promise that the holder of the first Dependent Rights has the right to sell on his own power the object of dependent rights if the debtor is injured by the promise".

Understanding the above promise, that creditors can promise by giving dependents the right of authority to sell the object of dependent rights on their own power, if fulfilled the condition, that the debtor default. The words "can be included in the promises" in Article 11 paragraph (2) of the Uuht, if connected with other promises mentioned above, it can be alleged that the creditor of the dependent rights holder is free to choose to promise such promises or not, and if he wishes that such a promise clause applies to himself and the dependents of third parties, Then he has to promise it. (Satrio, 2015) That the promises as in Article 11 paragraph (2) letter e of the UUHT are very different from the meaning of Article 6 of the UUHT which requires the authority of creditors to sell the object of dependent rights on their own power, can be interpreted the rights / authority of creditors it is not because it was promised but the right / authority of creditors obtained because the law stipulates it (ex lege).

The right to sell on one's own power granted by law (ex lege) is intended to break through the legal formalities of the event. This can be known because the implementation of the parate executie was carried out by the first creditor of the holder of Dependent Rights through a general auction, as well as taking repayment from the proceeds of the sale. The existence of the first Dependent Rights holder has the right to sell the object of dependent rights on his own power (parate executie) it turns out that no Indonesian scholar disavows even though the opinion of Indonesian scholars was expressed at the time of parate executie. As referred to in Article 1178 paragraph (2) of B.W., Some expressly admit, that without going through the court according to Article 1178 paragraph (2) B.W. a first mortgage holder can immediately auction his mortgage guarantee through the auction office, if it is expressly promised in the Mortgage Deed (met beding van eigenmachitige verkoop). (Gandasubrata, 1987) Even the author agrees with Stein who has outlined earlier, that the promise of ex 1178 paragraph (2) B.W. is an effort or means that is deliberately held for creditors to be able to get the money back by cheaper means. Ease of using the means of Article 6 of uuht because the implementation of the sale is carried out only through public auctions, without having to ask for the fiat of the Chairman of the District Court. Against the cost of implementing parate executie is cheaper than the execution of executie using the executory title, because it does not bear the cost to apply for a fiat executie Of The Chairman of the District Court. This is because if the execution procedure through the legal formalities of the event, then the process passed takes a long time and complicated the procedure, so it is feared that creditors will be reluctant to provide credit with mortgage guarantees (Dependent Rights), especially if the amount of the bill is not large. It will be felt that there is no draw between the amount to be charged with all effort, cost and especially the time it takes to get back the bad credit.

On the other hand, so that creditors are also protected from the actions of debtors who are not appropriate, unfit or even do not have good faith, then the formation of the law provides convenience to creditors, so that creditors can get their money in an easier and cheaper way, then Article 6 of the Uuht which ex lege can also strengthen the position of creditors when the debtor is injured promise, namely by providing provisions that can be used in the form of the right to sell themselves the object of guarantee of one's own power to take out the need for loans, namely as found in Article 6 of the UuHT. The article was prepared by the legislator as an excellent means for adjustment to economic needs and there is no doubt that Article 6 of the Uuht is the legal basis for the enactment of parate executie on the object of Dependent Rights while the debtor wanprestasi.

The execution procedure as intended in Article 6 of uuht, the first creditor of the holder of dependent rights simply submits an application for the implementation of the auction to the State Auction Office. The right of creditors to sell the object of dependent rights on their own power in public, has been submitted by law itself to the creditors of the first dependent rights holder. That authority is not obtained from the grantor of dependent rights but is already in itself to him, on the basis of the law itself giving to him. (Satrio, 2015:220) Any request for auction sellers through the intermediary of the Auction Office; should not be rejected by the auction official, as long as the request still covers the legal area of the auction office concerned. (Harahap, 313) To implement the 
provisions of Article 6 of the Uuht there has been an implementation regulation as stipulated in the Circular Letter of the State Agency for Receivables and Auction Number: SE-21/PN/1998 on instructions for the implementation of Article 6 of the UuHT and the Circular Letter of the State Agency for Receivables and Auction Number: SE-23/PN/2000.

That from the results of the author's research, banks that have carried out execution parate based on Article 6 of uuht, among others P.T. Bank Internasional Indonesia, PT. Bank Danamon Indonesia Tbk Bandung Branch, PT. Bank Negara Indonesia (Persero) Tbk. While the State Auction Office (KP2LN) which conducts auction sales on the basis of Article 6 of the UuHT is KP2LN Jakarta IV and KP2LN Bandung II. (Galamedia Daily, 2004:3).

The reasons for the acceptance of the auction application on the basis of Article 6 of the Uuht by the State Auction Office mentioned above include article 7 of the Auction Regulation (Vendu Reglement Ordinance of February 28, 1908 LN. 1908-189), which is that: The auction official is not authorized to refuse the request for its intermediary to hold an auction sale in his area, so that the auction official must fulfill every auction request submitted at the auction office in his area, No exception for auction requests on the basis of execution parate (as stipulated by Article 6 of uuht).

In conducting the auction on the basis of Article 6 of uuht, researchers interviewed the President Director of the Auction House PT. Triagung Lumintu Bpk. Ir. Hardiyanto Hoesodo, who stated that the auction hall led by him has often conducted auctions on the basis of Article 6 of the UuHT which covers all areas of Java even outside Java, namely in Lampung, Denpasar and even abroad such as in Singapore. (Hardiyanto, 2017).

As for the State Auction Office (KPZLN) as the executor of the auction sale of dependent rights objects on the basis of Article 6 of the UUHT, there is a difference of opinion in the implementation of the auction of dependent rights objects on the basis of Article 6 of the UUHT. As well as the Office of Receivables and State Auction Services (KPZLN) Jakarta II, states that the implementation of execution parate must be preceded by fiat from the Chairman of the District Court, while the other State Auction Office is willing to carry out auction sales without the fiat of the Chairman of the District Court, as the reason refers to the Explanation of Article 14 paragraph (2) and paragraph (3) of the UuHT, and hence the right of creditors as holders of dependent rights, In the implementation of parate execution of Dependent Rights equated with execution, certificate of Dependent Rights, because both must get the fiat of the Chairman of the District Court, another reason the Office of Receivables and State Auction Services (KP2LN) Jakarta II in implementing Article 6 of uuht get obstacles in the form of lawsuits, reported to the police, and emptying of the object of dependent rights auctioned. On the basis of these reasons, KP2LN Jakarta II took a stand in the implementation of Article 6 of uuht, creditors are requested to get fiat from the Chairman of the District Court. In contrast to the Office of Receivables and State Auction Services (KPZLN) Bandung II, which states that the implementation of parate executie without having to be preceded by fiat from the Chairman of the District Court, because the implementation regulations on Article 6 of the UUHT have existed so that it is only to carry it out. This shows that the implementation of the parate execution of Dependent Rights is still not comprehensively carried out, because there are some KP2LN who are not willing to carry out.

Based on the provisions of Article 6 of the Uuht it can be interpreted that the right to sell on one's own power is the object of dependent rights when the debtor wanprestasi is the implementation of the simplified right of execution, which is now granted by law to the creditors of the first dependent rights holder, meaning that in the exercise of such rights there is no need to go through the courts and does not need to be subjected to the legal procedure of the event. Thus the creditor holding the first Dependent Rights has the right to sell the object of dependent rights on their own power through the auction can directly come and ask the head of the Auction Office to conduct an auction on the rights of the dependents concerned.

In connection with the general auction based on Article 6 jo Article 20 paragraph (1) of the UUHT there are 3 (three) views in the environment of experts or legal practitioners (Bachtiar, 2001). First, there are those who consider that the auction of dependent rights is based on a promise that gives power to sell and this is classified as a voluntary auction. As a voluntary auction process, it still requires approval and auction limit price from the dependent rights giver. In practice it is very difficult to obtain auction approval from the debtor, and if any object of dependent rights is auctioned and then the issue of emptying or execution of riel, then the previously not involved court will reject the application of the auction buyer. The second view, considerIng Article 6 jo Article 20 UUHT is a parate executie therefore does not require the approval of the debtor and does not require court intervention. The execution of dependent rights in the future refers to the Auction Regulations and other implementations. Thus at this time in accordance with the second view, then formally the parate executie of the First Dependent Rights Holder can be carried out by the Bank (both Private Bank and Government Bank by submitting a dependent request to the state Auction Office.

The third view, considers that the general auction of dependent rights under Article 6 of the UuHT is not a parate executie but an execution for the First Tangungan Rights Holder. The basis of this view is the auction of the object of Dependent Rights based on Article 6, it can only be implemented if there is already an Act of 
Disobedience Rights and the serfifikat of Dependent Rights with the irahs "For the Sake of Justice Based on the Supreme Divinity". Therefore, based on Article 26 of uuht jo Article 224 H.I.R./258 R.Bg. according to this third view the auction of the first dependent rights must be by order and under the leadership of the Chairman of the District Court. This view is reinforced by the existence of Article 14 of the Uuht which mentions the general auction at the behest of the Chairman of the District Court..

That seeing from the process of implementing parate executie as intended in Article 6 of uuht compared to the execution procedure carried out according to Article 224 H.I.R. (Certificate of Dependent Rights and Grosse acte debt recognition) in which creditors must first apply to the Chairman of the District Court to get fiat, then the first creditor has facilities, among others: ease of execution procedure, fast time, cheap and simple costs because without going through or preceded by the procedure of confiscation, the certainty in the sale of collateral objects by auction, the existence of exceptions to the execution of the legal formalities of civil events, prioritizes the repayment of receivables rather than selling collateral objects through execution based on the executory title in the Certificate of Dependent Rights because it is intended only for the first creditors of dependent rights holders, in a means to get the money back.

Based on the arrangements about the process of execution parate implementation and its implementation regulations and based on the opinions of some hukurn experts about the above executie parate, it can be understood, if the debtor is injured by promise, it turns out that the implementation of the right of creditors of the First Dependent Rights to sell on their own power (parate executie) whose sale through auction, is faster the process for repayment of creditors' receivables than the implementation by using the itel executory (Court Ruling or Certificate of Dependent Rights).

\section{CONCLUSION}

1.Legis Ratio of Article 6 of Law No. 4 of 1996 concerning The Right of Dependents on Land And Objects Related to Land is the essence of parate execution from easy and fast execution is creditors can easily and effectively obtain repayment of receivables. The execution of dependent rights is actually with the birth of law No. 4 of 1996 concerning the Right of Dependents on Land And Objects Related to Land does not require fiat from the chairman of the district court. So that if the procedure of carrying out parate executie is equated with the execution procedure according to Article 224 H.I.R./258 R.Bg. as intended in Article 14 of the UUHT, it reaffirms the reins of the implementation of the parate executie institution. The procedure of execution of mortgages as the basis for the execution of Dependent Rights does not mean that the procedure of hypocrisy execution applies to all executions of Dependent Rights, including execution under Article 6 of the Uuht, but is only devoted to the execution of the executory title contained in the certificate of Dependent Rights as referred to in Article 14 paragraph (2) of the UUHT.

2.The arrangement of The Execution of Dependent Rights by prioritizing legal certainty and legal protection for each party with the main purpose of Parate execution is to provide real benefits in the form of convenience and efficiency of time and other conveniences to all parties for the process of execution of dependent rights. With an economic basis that demands all fast-paced and practical then it is no longer relevant if the implementation of execution parate must be through the chief's fiat.

\section{BIBLIOGRAPHY}

Kompilasi Hukum Perikatan.2001. Citra Aditya Bakti, Bandung.

,2012. Undang-undang Nomor 21 Tahun 2011 Tentang Otoritas jasa Keuangan. Anfaka Perdana. Surabaya

Adrian Sutedi. 2014. Aspek Hukum Otoritas Jasa Keuangan. Penerbit Raih Asa Sukses. Jakarta.

Fuady, Munir. 2002. Hukum Perkreditan Kontemporer, Citra Aditya Bakti, Bandung.

Hadjon Philipus M. dan Tatiek Sri Djalmiati. 2005. Argumentasi Hukum, Gajah Mada University Press, Yogyakarya.

Harahap, Yahya M. 1997. Hukum Acara Perdata Peradilan Indonesia, Zahir Trading Co, Medan.

Herlien Budiono. 2014. Ajaran Umum Hukum Perjanjian dan Penerapannya di bidang Kenotariatan. PT. Citra Aditya Bakti. Bandung.

John Rawls. 2011. Teori Keadilan. Pustaka Pelajar. Yogyakarta.

Juli Irmayanto dkk, 2002. Bank dan lembaga keuangan, Universitas trisaksi, Jakarta.

Kasmir. 2003. Bank dan Lembaga Keuangan Lainnya. Edisi Revisi. PT Raja Grafindo persada.Jakarta.

M.Manullang. 1995. Dasar-dasar Manajemen, Ghalia Indonesia: Jakarta.

Marzuki, Peter Mahmud. 2006. Penelitian Hukum, Kencana, Jakarta.

Mertokusumo, Sudikno.2005. Mengenal Hukum Suatu Pengantar, Liberty, Yogyakarta.

Soerjono Soekanto. 2004. Pengantar Penelitian Hukum. Universitas Indonesia. Jakarta. 
Rebekka Dosma Sinaga. 2013. Sistem Koordinasi Antara Bank Indonesia Dan Otoritas jasa keuangan Dalam Pengawasan Bank Setelah Lahirnya Undang-Undang Nomor 21 Tahun 2011 Tentang Otoritas Jasa Keuangan, Jurnal Hukum Ekonomi Universitas Sumatera Utara.

Siti Sundari. 2011. Laporan Kompendium Hukum Bidang Perbankan, Kementrian Hukum dan HAM RI, Jakarta.

Sjahdeni ST. Remy. 1993. Hak Tanggungan, asas-asas, ketentuan-ketentuan pokok dan masalah yang dihadapi oleh perbankan (Suatu Kajian mengenai Undang-Undang Hak Tanggungan), Alumni, Bandung.

Sofwan, Sri Soedewi Masychun. 1981. Hukum Jaminan Di Indonesia Pokok-pokok Hukum Jaminan dan Jaminan Perorangan, Liberty, Yogyakarta.

Subekti. 1982. Jaminan Jaminan untuk Pemberian Kredit Menurut Hukum Indonesia, Alumni. Bandung.

Tim Penyusun Kamus Pusat Pembinaan dan Pengembangan Bahasa. 1990. Kamus Besar Bahasa Indonesia, Balai Pustaka: Jakarta. 